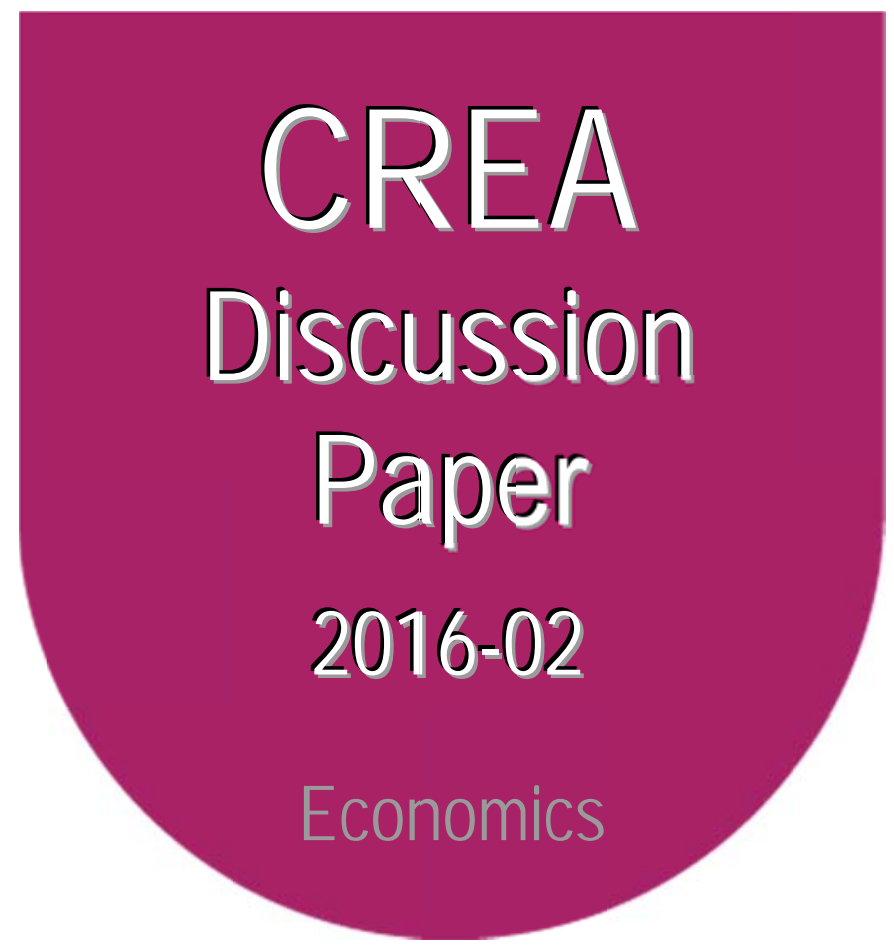

Center for Research in Economics and Management University of Luxembourg

\title{
The evolution of immigration and asylum policy in Luxembourg: insights from IMPALA
}

available online : http://wwwfr.uni.Iu/recherche/fdef/crea/publications2/discussion_papers

Michel Beine, CREA, Université du Luxembourg Bénédicte Souy, CREA, Université du Luxembourg

January, 2016

For editorial correspondence, please contact: crea@uni.lu

University of Luxembourg

Faculty of Law, Economics and Finance

162A, avenue de la Faïencerie

L-1511 Luxemboura

The opinions and results mentioned in this paper do not reflect the position of the Institution 


\title{
The evolution of immigration and asylum policy in Luxembourg: insights from IMPALA
}

\author{
Michel Beine ${ }^{1}$ \& Bénédicte Souy ${ }^{2}$
}

\begin{abstract}
January 2016
Abstract

This article presents and discusses the evolution of immigration policy of Luxembourg concerning the entry of economic, family related and humanitarian migrants. To that aim, we rely on some of the data of the IMPALA project that codes from immigration laws the entry conditions in a set of immigration countries. We focus on some entry tracks specific to skilled and unskilled migrants and compare some of the conditions prevailing in Luxembourg with those observed in France, the US and Australia. We also propose a narrative analysis of the changes in the Luxembourgish regulation since the end of the $19^{\text {th }}$ Century. We show that Luxembourg has improved its immigration system over time and follows mainly reforms introduced in the other European countries and at the European level.
\end{abstract}

Keywords: IMPALA project, Immigration policy, Asylum policy, Luxembourgish regulation JEL classification: K 37, F22, J08, J61

\section{Introduction}

Along with the recent immigration crisis in Europe, debates about the future stance of the immigration policy in Europe have been taking place all over the world. Calls for more restrictive immigration policies have been opposed by proposals towards more selective and opened immigration policies in European countries.

While these debates over immigration policy are useful, we should acknowledge that there is scarce scientific information about how immigration policies impact the inflow of immigrants. There is an extensive literature in economics and social sciences about the determinants of international migration flows (see Mayda, 2010; Beine, Bertoli and Fernandez-Huerta-Moraga, 2015 among many others). This literature has identified many

\footnotetext{
${ }^{1}$ Michel Beine: CREA, University of Luxembourg, 162a Avenue de la Faïencerie, L-1511 Luxembourg, e-mail : michel.beine@uni.lu

${ }^{2}$ Bénédicte Souy: CREA, University of Luxembourg, 162a Avenue de la Faïencerie, L-1511 Luxembourg, email: benedicte.souy@uni.lu/ benedicte.souy@gmail.com
} 
determinants such as geographic distance, language (Adsera and Plytikova, 2015), wage differentials (Grogger and Hanson, 2011), migrants network (Beine, Docquier, Ozden, 2011), business cycles (Beine, Bourgeon and Bricongne, 2015) or even culture (Belot and Erdeveen, 2012). These determinants fall into the category of self-selection factors, i.e. factors that impact the decision to emigrate or not on the part of prospective migrants.

The literature identifying out-selection factors, i.e. policies that hosting countries implement to select the immigrants, is much less developed. The main reason is the relative unavailability of measures of immigration policies that are comparable across countries and over time. This contrasts with the important development of indicators of trade policies that impact the magnitude and patterns of exchanges of goods and services between countries (Anderson and Van Wincoop, 2004). Measuring immigration policies is of course not easy since this implies to quantify restrictions that are qualitative in nature.

Fortunately, a couple of projects have started in order to fill this important gap. Among various projects, the IMPALA projects aims at creating data capturing the various restrictions implied by the immigration policies in place in the main hosting countries. The project aims at using a harmonized methodology to code in details the various policies affecting the inflow of different categories of prospective immigrants. The project is conducted within a research consortium to which the University of Luxembourg belongs. ${ }^{3}$ In turn, this allowed to code the Luxembourgish immigration policy.

This paper takes advantage of the new coding progress of the Luxembourgish immigration policy to give an overview of its evolution over time. We also provide a quick comparative perspective by presenting in parallel recent evolutions in other immigration countries such as France, the US and Australia. We show that the implementation of an explicit immigration policy in Luxembourg is quite recent and that the evolution basically reacts to progress made at the European level and in neighboring countries. Nevertheless, we find that the recent announced measures go in the desirable direction and are in line with the overall trend observed in many countries in terms of increasingly selective immigration policies.

The paper is organized as follows. Section 2 present the situation of immigration in Luxembourg and provide some key figures. Section 3 present the Impala project and its

\footnotetext{
${ }^{3}$ The research consortium includes Harvard University, the London School of Economics and Political Sciences, the University of Sydney, the University of Amsterdam and the University of Luxembourg.
} 
contribution to the literature on immigration policies measures. Section 4 presents the evolution of the Luxembourgish immigration policy and provides details about the Impala measures. Section 5 concludes.

\section{Key characteristics of immigration in Luxembourg}

Luxembourg is definitely an immigration country. Due to its booming economy, Luxembourg has attracted important waves of immigrants since the mid Eighties. Luxembourg is the most open country in terms of immigration among OECD countries, with $45.9 \%$ of foreign born people in its residing population. This proportion has undergone a very rapid increase since the 90 's: in 1991 , this proportion amounted to $27 \%$ only.

Immigration in Luxembourg has traditionally been dominated by inflows of people coming from the other European countries. The proportion of immigrants from European countries was about $85 \%$ in 2015 . Still, given the high immigration rate, the absolute number of extra-European immigrants amounts to 35000 , a significant number for a small country like Luxembourg.

Luxembourg is also characterized by the existence of important diasporas, i.e. population of immigrants living in Luxembourg and originating from a specific country. A well-known diaspora in Luxembourg is the Portuguese diaspora, with more than 90000 people originating from Portugal and its former colonies (e.g. Cap Verde). This has led to particular developments that the country has to take into account.

Luxembourg also relies heavily on immigrants for the development of its economy. It is once again the first OECD country in terms of the share of foreigners in the domestic labour force ( $71 \%$ in 2013). The development of a set of sectors such as the financial sector, the IT industry, auditing institutions or higher education institutions such as its university relies heavily on the attraction of skilled foreign workers. Another noticeable feature is the reliance on cross-border workers coming from neighboring countries (France, Germany, Belgium). They represent almost $50 \%$ of the domestic labour force.

Understanding the important increase in the number of immigrants to Luxembourg implies to identify the factors that explain international immigration flows. Fortunately, there is a large literature in social sciences that has specifically dealt with that (see for a survey Beine, Bertoli and Fernandez, 2015). Usual factors identified in that literature concern wage 
differentials, networks, distance or linguistic proximity. On top of that, immigration policy sensu lato, i.e. restrictions to mobility and conditions of entry of applicants, is expected to play a significant role. This implies in turn to collect data reflecting the various dimensions of immigration policy. This is the main purpose of the IMPALA project on which we rely here to discuss and compare immigration policy in Luxembourg.

\section{The Impala project}

\subsection{The Impala project}

Despite some recent efforts, there are no comprehensive, cross-nationally comparable data on immigration policies and no established method for classifying, measuring, and comparing immigration laws and policies over countries and time.4 This is a major problem for applied research as it makes it extremely difficult to make precise and meaningful empirical claims about immigration regulations in a comparative or historical perspective. Recent contributions such as Ortega and Peri (2009) or Demig (2015) capture immigration policies through the major reforms in terms of admission of economic immigrants. Therefore, they do not provide measures that are comparable across countries at a given point in time. Furthermore, they provide aggregate measures for all types of immigrants and overlook the heterogeneity of policies across targeted immigrants. Instead, the IMPALA project aims at providing a detailed picture of immigration policies for a large set of categories of migrants (see section 3.2) that are comparable across countries. Helbling et al. (2013) also propose indicators of immigration policies based on experts judgement. The IMPALA approach avoids the pitfalls of using subjective assessments by coding directly from immigration laws prevailing in the domestic legislation.

To that aim, the project involves collaborative, interdisciplinary research to classify and measure the character of the major categories of immigration policy, including economic migration, family reunification, asylum and humanitarian migration, student migration, and acquisition of citizenship. Each country's laws and regulations are coded annually using a common standardized list of questions about the character of such regulations, with coding decisions based on transparently citing written laws and regulations. The resulting data provide comparable, valid and transparent measures of immigration regulation that captures the nuanced details of immigration law but also provides a basis to estimate the restrictiveness

\footnotetext{
${ }^{4}$ While the term "immigration policy" generally refers to both policies of admission and integration, our project focuses largely on admission laws and regulations.
} 
of such regulations at the level of the country, year, and particular aspect of migration and migration law.5

\subsection{Categories of policies}

The IMPALA project is divided in five main categories of immigration covering the major areas of national immigration policies: economic migration, family reunification, student migration, humanitarian migration, irregular migration, acquisition and loss of citizenship for migrants residing in the country under investigation and the bilateral agreements. ${ }^{6}$

Economic migration encompasses regulations for workers, investors and entrepreneurs. Family reunification relates to the sponsor of the family members (partner, children, parents and extended family members), and is further divided into 2 sub-categories: (i) one when the sponsor can be considered as a permanent resident (citizen of the State, EU citizen with permanent residency etc.), (ii) the second one when the sponsor is granted a temporary permit in relation with, for instance, his work status (salaried employee, researcher, student, etc...). Student migration encompasses regulations affecting prospective university, school, vocational and language students. Humanitarian migration covers regulations for asylum seekers, refugees, subsidiary protection, temporary protection, residence permits for personal reasons (such as domestic violence), medical reasons and for victims of human trafficking.

\subsection{The entry track approach}

The concept of entry track is central in the project and characterizes the originality of the IMPALA approach. A given entry track corresponds to a specific way of entering the country within a category. Such modes of entry are normally distinguished by the purpose of migration and by the characteristics of the participants. For example, one long-established track of entry is the H-1B Visa offered in the United States under the Immigration and Nationality Act of 1965 which allows employers to temporarily sponsor and employ foreign workers with a minimum level of education and in specific professional occupations.

\footnotetext{
${ }^{5}$ See Gest et al. (2014) for an extensive discussion of these conceptual issues and the way they are addressed in the IMPALA project.

${ }^{6}$ In addition to these five main categories, IMPALA aims at coding two additional categories. Irregular migration relates to immigrants entering a country without prior authorization and to those who may be deported or excluded. The bilateral agreements group refers to preferential treatment granted with respect to a specific country of origin, as opposed to the general policy that is applicable to all.
} 
The concept of entry track is similar to that of a visa but can be more or less inclusive depending on the similarities (or differences) in the ways countries treat various types of immigrants. To illustrate, many countries admit seasonal workers, often through temporary migration programs. Some, such as France, Switzerland and the United Kingdom, have lumped all seasonal workers under one category of entry while others, including the United States, have created multiple tracks of entry that distinguish between agricultural and nonagricultural workers. We code these tracks separately when they are treated as such within the national legislation.

The IMPALA project is based on surveys that are applied to immigration laws. In particular, questions are asked at country level or at the entry-track level. When the regulation is the same for all the entry-tracks in the group, the question is asked at the country level. When the answer is different across tracks, the question is asked at the entry-track level.

Table 1 below reports the number of questions in the current IMPALA database, according to the different categories, and with the distinction between the major questions and the auxiliary ones. The aim of the auxiliary questions is to provide more details about a specific aspect of the regulation.

Table 1 Number of major and auxiliary questions by category in IMPALA

\begin{tabular}{|l|c|c|c|}
\hline Category & $\begin{array}{c}\text { Number of major } \\
\text { questions }\end{array}$ & $\begin{array}{c}\text { Number of } \\
\text { auxiliary questions }\end{array}$ & $\begin{array}{c}\text { Total number } \\
\text { of questions }\end{array}$ \\
\hline Economic (country level) & 6 & 2 & 8 \\
\hline Economic (track level) & 52 & 710 \\
\hline $\begin{array}{l}\text { Family / Dependent of } \\
\text { entrants (country level) }\end{array}$ & 16 & $43+25=68$ & 136 \\
\hline $\begin{array}{l}\text { Family / Dependent of } \\
\text { entrants } \\
\text { track level) }\end{array}$ & $39+29=68$ & 33 & 72 \\
\hline Student (track level) & 39 & 40 & 115 \\
\hline Humanitarian (country level) & 75 & 29 & 74 \\
\hline Humanitarian (track level) & 45 & & \\
\hline
\end{tabular}




\subsection{Evolution of the Entry-tracks in Luxembourg}

\subsubsection{Economic group}

In 1972, in Luxembourg, there were 9 different identified entry-tracks related to economic immigration. A first distinction identifies two general sub-categories: EU nationals (Salaried employee, Employee provider of community services and Self-employed) and third national workers (immigrants with work permits A, B, C and D, Posted workers and Selfemployed.)

In 2008, the Luxembourgish government decided to reform the immigration regulation. This reform led to an evolution in the number of entry-track for the Economic category with 15 entry tracks. The work permits A, B and C were divided in sub-categories: salaried employees, seasonal workers, highly qualified workers, holders of the European Blue Card, Intra-corporate transferees, Researchers, Sport persons, Salaried employees with a longterm residence in another EU country, highly qualified workers with a long-term residence in another EU country and Employee provider of community services.

Following the reform of 2008, each entry track has different specific criteria. We can identify a political willingness from the Luxemburgish government to alter the main objective of immigration and to be able to choose more in detail which kind of migrants are admitted in the country.

Figure 1 reports for the sake of comparison the evolution of number of entry-track for six countries included in the IMPALA database including Luxembourg. 
Figure 1: Evolution of entry tracks for economic migration, 1990-2008

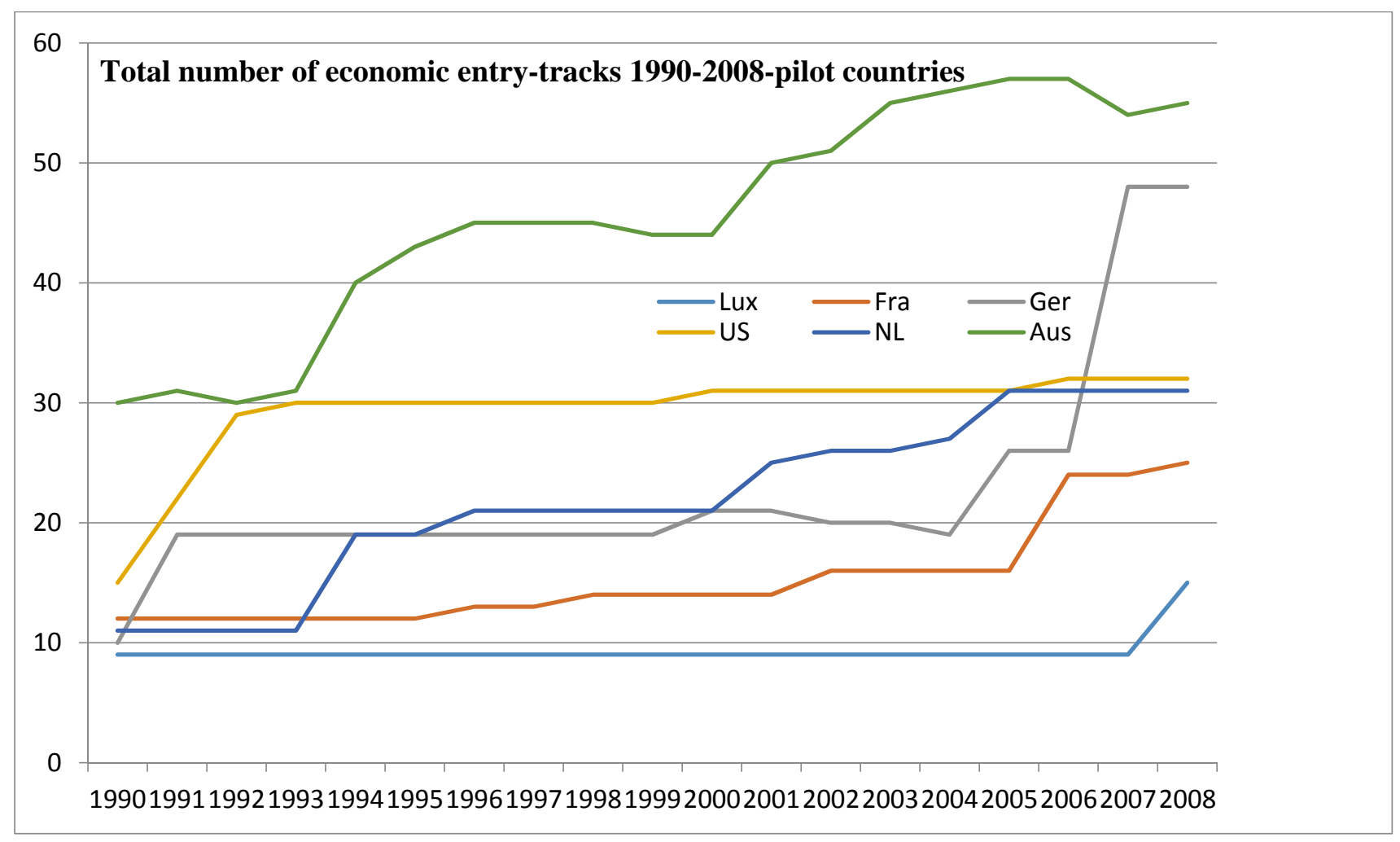

\subsubsection{Humanitarian group}

Concerning Humanitarian immigration, we can identify three major evolutions of the policy in Luxembourg between 2000 and 2008. Before 2000, only the entry-track Refugee according to the Geneva Convention was existing. In 1992/1993/1994 Luxembourg used 2 others types of humanitarian stay permits; (i) the temporary protection and (ii) the tolerance certificate (only with specific nationalities). This amounted, before 2000, to 3 entry-tracks.

The first big change occurred in 2000 with the introduction of the Temporary protection and the Tolerance certificate in the national legislation. The second one took place in 2006 with the introduction of the subsidiary protection (implemented through the transposition of the European directive 2004/83/CE) and special conditions for the unaccompanied minors (there were 6 entry-tracks as of 2006). The last big change occurred in 2008 with the introduction of the concept of stay permit for personal reasons, such as Domestic violence, Exceptional serious humanitarian motives, Medical reasons or Victims of human trafficking (10 entry-tracks in 2008). 


\subsection{Selection of questions}

As explained before, in order to characterize the entry conditions for a specific entry track, IMPALA relies on questions aiming at capturing these conditions. Tables 2 and 3 report a sample of the questions (country and track level) applied to the Economic category; Table 4 does the same for the Family group. The upper panel reports the questions that are applied at the country level, i.e. to all entry tracks identified within that category, while the lower panel reports the questions whose outcomes can display some variation across the various entry track.

\subsubsection{Economic group}

Table 2: Sample of questions in the Economic category/country level questions

\begin{tabular}{|l|c|c|c|c|c|c|c|c|c|}
\hline Example of questions & $\begin{array}{c}\text { Major/ } \\
\text { Aux. Q }\end{array}$ & $\begin{array}{c}\text { FR } \\
\mathbf{2 0 0 8}\end{array}$ & $\begin{array}{c}\text { FR } \\
\mathbf{1 9 9 9}\end{array}$ & $\begin{array}{c}\text { LUX } \\
\mathbf{2 0 0 8}\end{array}$ & $\begin{array}{c}\text { LUX } \\
\mathbf{1 9 9 9}\end{array}$ & $\begin{array}{c}\text { US } \\
\mathbf{2 0 0 8}\end{array}$ & $\begin{array}{c}\text { US } \\
\mathbf{1 9 9 9}\end{array}$ & $\begin{array}{c}\text { AUS } \\
\mathbf{2 0 0 8}\end{array}$ & $\begin{array}{c}\text { AUS } \\
\mathbf{1 9 9 9}\end{array}$ \\
\hline $\begin{array}{l}\text { Does the country } \\
\text { operate an annual } \\
\text { category level quota? }\end{array}$ & Major & No & No & No & No & Yes & Yes & Yes & Yes \\
\hline $\begin{array}{l}\text { What is the annual } \\
\text { category level quota? }\end{array}$ & Aux. & N/A & N/A & N/A & N/A & 140000 & 140000 & 133500 & 35330 \\
\hline $\begin{array}{l}\text { Does the country } \\
\text { operate a points test? }\end{array}$ & Major & No & No & No & No & Inf. & Inf. & Yes & Yes \\
\hline $\begin{array}{l}\text { Does the country adopt } \\
\text { a labour shortage test } \\
\text { (or list)? }\end{array}$ & Major & Yes & No & No & No & Inf. & Inf. & Yes & Yes \\
\hline
\end{tabular}


Table 3: Sample of questions in the Economic category/ Track level questions

\begin{tabular}{|c|c|c|c|c|c|c|c|c|c|}
\hline Example of questions & $\begin{array}{l}\text { Major/ } \\
\text { Aux. Q }\end{array}$ & $\begin{array}{c}\text { FR } \\
2008 \\
\end{array}$ & $\begin{array}{c}\text { FR } \\
1999 \\
\end{array}$ & $\begin{array}{l}\text { LUX } \\
2008 \\
\end{array}$ & $\begin{array}{l}\text { LUX } \\
1999 \\
\end{array}$ & $\begin{array}{c}\text { US } \\
2008 \\
\end{array}$ & $\begin{array}{c}\text { US } \\
1999 \\
\end{array}$ & $\begin{array}{l}\text { AUS } \\
2008\end{array}$ & $\begin{array}{l}\text { AUS } \\
1999 \\
\end{array}$ \\
\hline \multicolumn{10}{|c|}{ Unskilled worker } \\
\hline $\begin{array}{l}\text { Must the employer undertake a labour } \\
\text { market availability test for this entry } \\
\text { track? }\end{array}$ & Major & Yes & Yes & Yes & Yes & Yes & Yes & No & $\mathrm{No}^{7}$ \\
\hline $\begin{array}{l}\text { Is the inclusion of the entrant's } \\
\text { occupation on a shortage list } \\
\text { considered for this track? }\end{array}$ & Major & Yes $^{8}$ & No & No & No & Yes & No & No & No \\
\hline $\begin{array}{l}\text { Is the entrant required to pay an } \\
\text { application fee? }\end{array}$ & Major & Yes & No & Yes & Yes & Yes & Yes & Yes & Yes \\
\hline What is the standard fee? & Aux. & $168 \mathrm{~F}^{9}$ & $\mathbf{n} / \mathbf{a}$ & $30 €$ & $200 \mathrm{LuF}$ & & & $\begin{array}{l}\$ 150 / \\
\$ 250\end{array}$ & $\begin{array}{l}\$ 150 \\
\$ 250\end{array}$ \\
\hline $\begin{array}{l}\text { Are educational qualifications } \\
\text { considered? }\end{array}$ & Major & Yes & No & Yes & No & No & No & No & No \\
\hline $\begin{array}{l}\text { Can the entrant sponsor family } \\
\text { members? (after admission of the } \\
\text { entrant - not on the same permit) }\end{array}$ & Major & $\begin{array}{c}\text { Yes } \\
\text { (Rest) }^{10}\end{array}$ & $\begin{array}{c}\text { Yes } \\
\text { (Rest) }\end{array}$ & $\begin{array}{c}\text { Yes } \\
\text { (Rest) }\end{array}$ & $\begin{array}{c}\text { Yes } \\
\text { (Rest) }\end{array}$ & Yes & Yes & No & No \\
\hline \multicolumn{10}{|c|}{ Skilled worker } \\
\hline $\begin{array}{l}\text { Must the employer undertake a labour } \\
\text { market availability test for this entry } \\
\text { track? }\end{array}$ & Major & No & No & No & Yes & No & No & No & No \\
\hline $\begin{array}{l}\text { Is the inclusion of the entrant's } \\
\text { occupation on a shortage list } \\
\text { considered for this track? }\end{array}$ & Major & No & No & No & No & Yes & No & No & Yes \\
\hline $\begin{array}{l}\text { Is the entrant required to pay an } \\
\text { application fee? }\end{array}$ & Major & $\mathrm{No}^{11}$ & No & Yes & Yes & Yes & Yes & Yes & Yes \\
\hline What is the standard fee? & Aux. & $\mathbf{n} / \mathbf{a}$ & $\mathbf{n} / \mathbf{a}$ & $30 €$ & 200LuF & & & $\$ 250$ & $\$ 250$ \\
\hline $\begin{array}{l}\text { Are educational qualifications } \\
\text { considered? }\end{array}$ & Major & $\mathrm{No}^{12}$ & No & Yes & No & Yes & Yes & Yes & Yes \\
\hline $\begin{array}{l}\text { Can the entrant sponsor family } \\
\text { members? (after admission of the } \\
\text { entrant - not on the same permit) }\end{array}$ & Major & Yes & Yes & Yes & $\begin{array}{c}\text { Yes } \\
\text { (Rest) }\end{array}$ & Yes & Yes & No & No \\
\hline
\end{tabular}

7 For Sport - Sports instructor under business arrangement, it's yes on 1999. (This is the exception it's why we didn't take it into account in the average we've done in this table.

8 This work permit "Salaried employee TCN" can be for some specific occupation on a shortage list, if the occupation is currently looking for salaried employee ("Pénurie de main-d'oeuvre"). These list of occupation are regional in France and available on the web-site: www.legifrance.gouv.fr

9 It was between 168 Euros and 1444 Euros, depending of the type of profession and the initial price of the visa paid by the applicant for his entrance in France. All explanations can be found in the IMPALA Database.

10 Yes (Rest) means the answer is Yes but with some restrictions, as a waiting period before being allowed to apply for the family reunification.

11 Nothing is mentioned in the «Circulaire interministérielle DPM/DMI2 nA ${ }^{\circ} 2005-542$ du 16 novembre 2005 relative aux taxes et droits dus à l'Agence nationale de l'accueil des étrangers et des migrations lors de l'admission au séjour et au travail des étrangers non communautaires »

12 In France nothing is mentioned in the law, it's the salary considered more than the education. 
In order to illustrate the contribution of Impala in identifying differentiated policies across types of migrants, we report the outcome of a set of questions for migrants that can be considered as skilled and other ones that can be considered as less skilled. The selection of these categories is not straightforward as the concept of skill is obviously not defined and used in the immigration laws: Therefore, this requires to make some arbitrary choices for each country under investigation. The entry tracks for unskilled migrants are chosen according to the following assumptions. For France, we choose the work permit "salaried employee TCN"; for Luxembourg we choose the work permit "salaried employee TCN" for 2008 and the "Work permit B" for 1999; for the United States we choose "H2B" ; for Australia we take an average between Sport visas (421), Media and Film Staff visas (423), Religious Worker visa (428) because these visas are for specific entrants, but when compared to other skilled visas, they do not have strict requirements in terms of educational/training qualifications, employment experience, language proficiency.

For the "skilled, or highly skilled" workers we make the following choice. For France, we choose the work permit "High skill executive officer of foreign company". For Luxembourg, we take the work permit "High skilled worker" in 2008 and the "Work permit B" in 1999. For the United States, we take the H1B visa while for Australia, we choose the Business Long-term visa (457).

The contents of Tables 2 and 3 suggest that there is a huge variation of policies across countries, years and entry tracks. For instance, before 2008, Luxembourg did not differentiate policies by skill level, in contrast with the other countries, including a European continental country like France. For instance, France discriminated between skilled and unskilled applicants in terms of compliance with a labour market test (availability of natives for that occupation). The same applied to the US policy. The outcomes of Tables 2 and 3 illustrate the many dimensions a policy can embrace to select the prospective immigrants.

\subsubsection{Family group}

In the IMPALA database, the family group is divided in two sub-groups: (i) if the sponsor can be considered as a permanent resident e.g. citizen, European citizen, permanent resident (the name of the group is "Family"; (ii) if the status of the family member is linked with the status of the sponsor (the name of the group is "Dependent of entrant"), e.g. partner of salaried worker, minor child of refugee etc. 
For the example below we selected two specific entry-tracks, the partner of the citizen and the partner of an unskilled worker. For the part of the table "2008/1999/ Partner of citizen", for France the exact name of the track selected is "Partner TCN of French citizen". For Luxembourg, it is "Partner TCN/EU of Luxembourgish citizen". For Australia, it is “Spouse Visa (309), (820)" and for the United States "Spouse of legal Permanent Resident (quota)".

For the part of the table "2008/1999/ Partner of unskilled worker", for France the exact name of the track selected is "Partner TCN of a salaried employee". For Luxembourg, it is "Partner TCN of a salaried employee" for 2008 and "Partner of a worker with a work permit B" for 1999. For Australia, it is an average between Partner of visas Sport (421), Media and Film Staff (423), Religious Worker (428) and for the United States, it is Partner of holder of an "H2B" visa. We selected 5 major questions which are common to the both set of questions mentioned in (i) and (ii).

The analysis of Table 4 below shows that the difference in the answers are essentially in the status received by the partner, more than in the conditions for bringing the family members. The major difference concerns the type of permit. For the partner of an unskilled worker, the same permit will be delivered in the United States and Australia, while the permit is "independent" in the European countries.

The question about the minimum income level shows the fact that only the foreigners in 3 countries over 4 must be able to sustain the finance cost of living in family. The family reunification is a right when you are a citizen of the country but a privilege when you are a foreigner. 
Table 4: Sample of questions in the Family category/ Track level questions

\begin{tabular}{|c|c|c|c|c|c|c|c|c|}
\hline Example of questions & $\begin{array}{c}\text { FR } \\
2008\end{array}$ & $\begin{array}{c}\text { FR } \\
1999\end{array}$ & $\begin{array}{l}\text { LUX } \\
2008\end{array}$ & $\begin{array}{l}\text { LUX } \\
1999\end{array}$ & $\begin{array}{c}\text { US } \\
2008\end{array}$ & $\begin{array}{c}\text { US } \\
1999\end{array}$ & $\begin{array}{l}\text { AUS } \\
2008\end{array}$ & $\begin{array}{l}\text { AUS } \\
1999\end{array}$ \\
\hline \multicolumn{9}{|c|}{ Partner of citizen } \\
\hline Is there a quota for this track? & No & No & No & No & Yes & Inf. $^{13}$ & No & No \\
\hline Is having medical insurance considered? & No & No & Yes $^{14}$ & No & No & Inf. & No & No \\
\hline $\begin{array}{l}\text { Is proficiency in the official language(s) } \\
\text { of the receiving country considered as } \\
\text { defined by the selecting country? }\end{array}$ & No & No & No & No & No & Inf. & No & No \\
\hline $\begin{array}{l}\text { Is there a minimum income level for the } \\
\text { resident? }\end{array}$ & No & No & No & No & Yes & Inf. & No & No \\
\hline $\begin{array}{l}\text { Is the entrant granted a temporary } \\
\text { permit? }\end{array}$ & Yes & Yes & Yes & Yes & Inf. & Inf. & Yes & Inf. \\
\hline \multicolumn{9}{|c|}{ Partner of unskilled worker } \\
\hline $\begin{array}{l}\text { Are entrant's dependents subject to a } \\
\text { quota? }\end{array}$ & No & No & No & No & No & Inf. & No & No \\
\hline $\begin{array}{l}\text { Is whether the entrant's dependent has } \\
\text { medical insurance considered? }\end{array}$ & $\mathrm{No}^{15}$ & No & Yes & No & No & Inf. & No & No \\
\hline $\begin{array}{l}\text { Is dependency of the entrant's dependent } \\
\text { on the principal applicant a requirement? } \\
\text { (e.g. financial/health related) }\end{array}$ & Inf. & Inf. & Inf. & Inf. & No & Inf. & Inf. & Inf. \\
\hline $\begin{array}{l}\text { Is there a minimum income level for } \\
\text { the principal applicant for the purpose of } \\
\text { bringing over entrant's dependents? }\end{array}$ & Yes & Yes & Yes & Yes & No & Inf. & Yes & Yes \\
\hline $\begin{array}{l}\text { Is the entrant's dependent granted a } \\
\text { temporary permit with the prospect of } \\
\text { being eligible to apply for transition to a } \\
\text { permanent permit? }\end{array}$ & Yes & Yes & Yes & Inf. & $\mathrm{No}^{16}$ & Inf. & No & No \\
\hline
\end{tabular}

13 "Inf." means no information available in the IMPALA database

14 The partner of the Luxemburgish citizen is assimilated to the partner of the EU/EEC citizen.

${ }^{15}$ The answer available in the IMPALA database is Not mentioned, but we decided for the analysis of this paper to consider the answer « Not mentioned» as No.

${ }^{16}$ The partner receives the same stay permit as the sponsor/ Same for Australia in 1999 and 2008 


\section{The Luxembourgish case}

\subsection{A short narrative description of the main immigration policy reforms in Luxembourg}

We can distinguish five different periods of migration policy in Luxembourg between 1893 and 2008 .

\subsubsection{From $1893^{17}$ " Loi du 30 décembre 1893 concernant la police des étrangers " to $1972^{18}$ "Loi du 28 mars 1972 concernant 1. L'entrée et le séjour des étrangers ; 2. le contrôle médical des étrangers ; 3. l'emploi de la main-d'œuvre étrangère. "}

During these 79 years, a couple of regulations ${ }^{19}$ were adopted to protect the Luxembourgish labour market from the foreigners and to regulate the number of foreigners allowed to live in the country. In all these regulations, the check of the labour market vacancy and the national preference treatment was mandatory for all foreign workers and all types of occupations. In all cases the government took into account the unemployment rate of the Luxembourgish workers, or the stance of the business cycle to adapt these restrictions to the labour market for the foreign workers.

The first measure to protect the labour market and the Luxembourgish workers from the "invasion of foreigners ${ }^{20}$ was the requirement to have a work permit to be allowed to work as a foreigner in the country ${ }^{21}$. The second one was the check the labour market vacancy and to give the national preference treatment for the Luxembourgish workers. As of 1923, this requirement was not only applicable for the delivery of the first work permit, but also each time the foreign worker wanted to change of employer. As of 1920, an exception was created for foreign workers and employees with a minimum monthly salary. Some specific occupations were also part of this exception regime (e.g. director). Between 1920 and 1936, there was an increase in the minimum salary requested to be exempted from the labour market

\footnotetext{
${ }^{17}$ Loi du 30 décembre 1893 concernant la police des étrangers.

${ }^{18}$ Loi du 28 mars 1972 concernant 1 . l'entrée et le séjour des étrangers; 2. le contrôle médical des étrangers; 3. l'emploi de la main-d'oeuvre étrangère.

19 Arrêté grand-ducal du 20 août 1920 concernant l'embauchage d'ouvriers de nationalité étrangère/ Arrêté grand-ducal du 21 août 1923 concernant l'embauchage d'ouvriers de nationalité étrangère/ Arrêté grand-ducal du 21 août 1926 concernant l'embauchage des ouvriers de nationalité étrangère/ Arrêté grand-ducal du 31 mai 1934 ayant pour objet d'introduire la carte d'identité, tel qu'il se trouve modifié par les arrêtés grand-ducaux des 15 juillet 1934, 31 octobre 1935, 12 août 1937, 7 juin 1938, 23 décembre 1952, 23 mai 1958 et 11 avril 1964.

20 Please note the name of the law : «Loi du 28 octobre 1920 destinée à endiguer l'affluence exagérée d'étrangers sur le territoire du Grand-Duché ».

${ }^{21}$ Arrêté grand-ducal du 20 août 1920 concernant l'embauchage d'ouvriers de nationalité étrangère
} 
availability process ${ }^{22}$. The third restrictive measure came into effect in 1949 with the creation of a new tax for the employers wishing to hire a foreign worker. This tax was applicable for all the requests of work permit for foreign workers.

The combination of these different measures made it more and more restrictive for foreign workers to access the Luxembourgish labour market, especially those with no specific qualifications.

An additional restriction of entry and stay on the Luxembourgish territory was introduced in 1934 through the requirement for foreign workers to hold a foreign identity card. This card was mandatory for people age 15 years old and more and was valid for 2 years. It was delivered under resource conditions for the foreigner and his family. The mandatory fee attached to the delivery of this card can also be considered as a restrictive measure applied to foreigners. It is worth noting that in the regulations on immigration between 1893 and 1972, nothing is mentioned about family reunification.

\subsubsection{Reform of 1972, "Loi du 28 mars 1972 concernant 1. L'entrée et le séjour des étrangers; 2. le contrôle médical des étrangers ; 3. l'emploi de la main-d'œuvre étrangère. "}

In 1972, Luxembourg modified its immigration policy to comply with the implications of EU membership. The regulations of the 30's did not make any distinction between European foreign workers and the other ones. The existing regulation had become inconsistent with the European regulation 38/64 about the free movement of workers inside the European community and the Directive of the Council of March $25^{\text {th }} 1964$ about the removal of restrictions of movement and stay of the European community workers and their family.

The old system with the delivery of the work permit to the employer (as opposed to the worker was no longer sustainable. With the economic development of Luxembourg, firms needed more and more foreign workers while the workers get more flexible and more prone to change job. Therefore, one of the major changes was the creation of the four ${ }^{23}$ work permits, to be delivered to the worker and no longer to the employer. Permits A, B and C became less restrictive over time: work permit A was valid for one year, one specific occupation and one specific employer; work permit B was valid for five years, one specific occupation but all

\footnotetext{
${ }^{22}$ Please not we will not considered the regulation in place from 1939 to 1945 , taker by the German authorities in place at that period in Luxembourg. We also notice during our research the cancelation as of 1945 of all measures taken by the German authorities in place in Luxembourg during the Second World War on the aspect of the immigration regulation.

23 Work permit $\mathrm{D}$ is for the trainee.
} 
employers; the work permit $\mathrm{C}$ was unlimited, and valid for all occupations and all employers ${ }^{24}$.

A couple of measures aimed at protecting the national labour market and the Luxembourgish employees were still in place. These included the requirement of a labour market vacancy, the prior declaration to the administration of a vacant job, the mandatory holding of a work permit and the existence of fees.

Until 2006 and the implementation of the European Directive 2005/71/CE dedicated to the researchers, as illustrated by the upper panel of Table 3, Luxembourg did not make any explicit distinction between the skilled and unskilled foreign workers or employees. The minimum level of salary allowing to be waived from the labour market availability test, in place during 50 years, was not mentioned in the 1972 law.

Family reunification was however not covered in the regulations that prevailed between 1983 and 1972. Regulation about family reunification only exits at the bilateral agreement level. Bilateral agreements played an important role with the immigration policy. The best illustration on the influence of the bilateral agreements on the family reunification application is the bilateral agreement with Portugal.

\subsubsection{Bilateral agreement with Portugal, May $20^{\text {th }}, 1970$, in force April $14^{\text {th }}, 1972$}

In the 50's Luxembourg started to conclude bilateral agreements to facilitate the entrance and the establishment of workers. The first large inflow were the Italian seasonal workers $^{25}$ and some cross-border workers from France ${ }^{26}$, Belgium $^{27}$ and the Netherlands ${ }^{28}$.

The most important bilateral agreement in terms of flow of workers was certainly the one signed with Portugal on May 20 $0^{\text {th }}, 1970$, in force as of 1972. In 1970, over 5.000 Portuguese were resident in Luxembourg, while in 2015, this number amounts to 92100

\footnotetext{
24 Règlement grand-ducal du 12 mai 1972 déterminant les mesures applicables pour l'emploi des travailleurs étrangers sur le territoire du Grand-Duché de Luxembourg (the indications of duration mentionned above are the one indicated in the initial version of the regulation. Modifications have been done across years and can be found on the web site www.legilux.public.lu)

25 « Arrangement relatif au recrutement de travailleurs agricoles en Italie, conclu le 6 avril 1948 entre les Gouvernements italien et luxembourgeois », in force April 29th, 1948

26 « Accord signé à Paris le 27 juin 1949, entre le Grand-Duché de Luxembourg et la France, relatif aux travailleurs frontaliers $»$, in force

27 « Convention concernant les travailleurs frontaliers, conclue le 17 avril 1950 entre les Parties contractantes du Traité de Bruxelles »

28 « Convention concernant les travailleurs frontaliers, conclue le 17 avril 1950 entre les Parties contractantes du Traité de Bruxelles »
} 
Portuguese residents. The fact that the Portuguese were allowed to join easily Luxembourg and to bring their family was not the only reason of this massive increase $(50 \%$ of the Portuguese currently residing in Luxembourg arrived after 1995) but it was definitely a major reason.

During the 60's and at beginning of the 70's, Luxembourg experienced a population decline. The Italian seasonal workers went back to Italy where the economic situation had improved since WW2 and Luxembourg refused them to bring their family ${ }^{29}$. As a result, Luxembourg favored the inflow of people coming from European countries. As Michel Barnich, first commissionner for immigration in Luxembourg relates "Tous les gouvernements que j'ai connus partageaient le sentiment général du pays que le recrutement des travailleurs étrangers devait se faire de préférence dans les pays européens, sans pour autant se fixer sur une nationalité déterminée, qui nous étaient les proches par leur culture et leurs traditions, ceci pour faciliter leur intégration”30. A number of Portuguese workers were already close to Luxembourg working on construction sites on the Moselle in France. Portugal was the perfect origin country to provide the required labour force.

Following the bilateral agreement, Portuguese immigrants became the first foreign community in Luxembourg. Workers settled with their family and this led to a more stable labour force that was necessary for the evolution of the Luxemburgish economy.

In absence of any existing legal regulation on family reunification, Luxembourg relied only on bilateral agreements. The Ministry alone determined criteria used in the decision process about family reunification. Examples of the necessary conditions of entry include the availability of accommodation, sufficient resources and holding of at least a work permit of type B. Many cases rejected by the Minister were brought in front of the administrative court, but in absence of any national specific regulation, only the article 8 of the European Convention of Human right was appreciated as a right of family reunification.

After 2005, following the approval of the European directive 2003/86/CE on family reunification, Luxembourg had to apply the criteria included in the directive as the standard

\footnotetext{
29 An addendum of the bilateral agreement with Italy was signed on 1963 to allow the family reunification process, but it was too late and the Italian seasonal workers, were already on their way to get back home. 30 This idea is presented by Marcel Barnich, first commissioner for immigration in Luxembourg, extract from "Les débuts du Service de l'Immigration; Souvenirs de M.Marcel Barnich, premier Commissaire à l'Immigration", Lëtzebuerg de Lëtzebuerger?, Le Luxembourg face à l'Immigration, ASTI, Editions Guy Binsfeld
} 
conditions for family reunification ${ }^{31}$. Between 2005 to 2008 (year of the implementation of the national regulation on family reunification and until the official transposition of the European directive $2003 / 86 / \mathrm{CE}$ on family reunification), Luxembourg used that directive as a legal basis for family reunification and tried to use it in front of court against the applicants.

\subsubsection{Reform of 2006, Asylum " ${ }^{32}$ "Loi du 5 mai 2006 relative au droit d'asile et à des formes complémentaires de protection "}

Some preliminary remarks are in order for a better understanding of the Humanitarian category. The first regulation governing the right of asylum was adopted in 1996. Before this, the refugee status was directly and only obtained on the basis of the Geneva Convention ${ }^{33}$. In 2000, a law implementing a European directive introduced the concept of Temporary protection. In 2006, the concept of Subsidiary protection (also deriving from a European directive) and some additional information for the Refugee status were introduced. The law of 2008 created an additional stay permit for humanitarian motives distinct from refugee regulations.

As the Luxembourgish legislation is quite recent for the humanitarian motives or based on various directives, we cannot notice any major difference over time. The only differences basically concern details. The most recent legislation provides more information about the application process and about the conditions of delivery of the different status etc... This point is particularly true for the Refugee status. The Geneva Convention used for the determination of the status until 1996 was quite imprecise from a procedural perspective. A minimum of criteria for the examination procedure was determined with the law of 1996, and completed by the law of 2006.

Therefore, it is more interesting to compare the positions of Luxembourg with respect to the other countries rather than its evolution over time. As an example, in France, we can notice there is several ways of applying for the asylum status. These are Refugee with the

\footnotetext{
31 Luxembourg didn't transpose in time the European directive 2003/86/CE on the family reunification and had to apply it if the applicant is required it (in front of court).

${ }^{32}$ Additional information about the asylum system in Luxembourg can be found in the book « Droit d'asile au Grand-Duché de Luxembourg et en Europe : Développement récents”, Gerkrath, Jörg, 2009, Ed. Larcier

${ }^{33}$ Convention de Genève de 1951 relative au statut des réfugiés et son Protocole additionnel de New York de 1967
} 
application of the Geneva Convention, Refugee as declared by the UNHCR and the Constitutional asylum ${ }^{34}$. This diversity does not exist in the Luxembourgish legislation.

\subsubsection{Reform of 2008 « Loi du 29 août 2008 portant sur la libre circulation des personnes et l'immigration "}

The new regulation of 2008 is the most recent one in Luxembourg. This law transposed six European directives: European directive 2003/86/CE about family reunification; European directive $2003 / 109 / \mathrm{CE}$ on the long-term residence of the third country nationals; European directive 2004/81/CE for the victims of human trafficking; European directive 2004/114/CE about the students; European directive 2005/71/CE for researchers and the European directive 2004/38/CE about the European citizens ${ }^{35}$.

With this new reform, the migration policy was completely repealed. The previous A, $\mathrm{B}, \mathrm{C}$ work permits were divided into new work permits with an explicit reference to the professional occupation (e.g.: work permit Salaried employee, Highly skilled worker, Researcher $^{36}$ etc.).

Different conditions applied to different work permits. A common feature to these different conditions is nevertheless the fact that the higher the salary and the skill level, the less restrictive the conditions of admission. ${ }^{37}$. The initial duration of the work permit (and stay permit) is also linked to the type of permit. Workers are free to choose their employer once they have the permit.

For the first time, the family reunification conditions are explicitly stated ${ }^{38}$. The right to bring one's family is linked to the status of the sponsor (e.g.: the salaried employee or researcher). Again we can see a difference in the required conditions for the sponsor to be allowed to apply for the family reunification according to the type of work permit of the sponsor. Once again, the higher the professional skills of the sponsor and the higher the wage, the less restrictive the conditions of family reunification.

\footnotetext{
${ }^{34}$ Article 711-1 and following of the « Code de l'entrée et du séjour des étrangers et du droit d'asile ». 35 The exact denomination of the directives can be found on the Luxembourgish parliamentary file number 5802 (http://www.chd.lu/wps/portal/public/RoleEtendu?action=doDocpaDetails\&id=5802\#)

${ }^{36}$ Loi du 29 août 2008 portant sur la libre circulation des personnes et l'immigration, article 42 and following

${ }^{37}$ For instance, the check of the labour market conditions is not applicable for the highly qualified work permit, but applicable for the salaried one.

${ }^{38}$ Loi du 29 août 2008 portant sur la libre circulation des personnes et l'immigration, article 68 and following
} 
This new regulation also includes for the first time a stay permit for humanitarian motives, such as domestic violence or Exceptional humanitarian motives ${ }^{39}$.

\subsection{Europeanisation of the Luxembourgish migration regulation.}

The reform of 2008 was definitely induced by the pressure from the European community. Between 2004 and 2008, because of the delay in implementing the European regulations, Luxembourg was condemned 4 times by the European Court of Justice and received one reasoned opinion as well as one formal notice ${ }^{40}$.

An interesting question is why Luxembourg did not transpose the directives within the requested time limits? One possible answer could be the lack of political will, and the fact that Luxembourg wanted to keep control on the issues mentioned in the directive. The other hypothesis can be the lack of human resources needed to transpose the directives over that period.

The defense of the Luxembourgish authorities' in front of the European court provides some answer. One of the major arguments, several times mentioned, is the application of the European directive (especially for the family reunification), even without any transposition in the national regulation ${ }^{41}$. In addition, we also found several national judgments with the explicit application of the content of the (non transposed) directives. During discussions, some political sources confirmed the second hypothesis, i.e. the lack of human resources.

The Luxembourgish law of 2008 became the European directive and principles in terms of migration. That structure of the law itself follows the structure of the directive proposed by the Council regarding the conditions of entry and stay for the third country nationals for salaried workers or self-employed immigrants.

\subsection{Variations of questions within the Economic and Family categories}

\footnotetext{
${ }^{39}$ Loi du 29 août 2008 portant sur la libre circulation des personnes et l'immigration, article 89 and following 40 European directive 2001/51/CE $\rightarrow$ Judgment of the Court C 449-04; European directive 2003/86/CE $\rightarrow$ Judgment of the Court C-57/07; European directive 2003/109/CE $\rightarrow$ Judgment of the Court C-34/07; European directive 2004/38/CE $\rightarrow$ Judgment of the Court C-294/07; European directive 2004/114/CE $\rightarrow$ reasoned opinion ; European directive 2005/71/CE $\rightarrow$ formal noticed.

41 Judgment of the Court C-57/07 « Dans son mémoire en défense, le Grand-Duché de Luxembourg ne conteste pas le manquement reproché. Il indique toutefois que, en pratique, il applique toutes les dispositions de la directive 2003/86 et que cette pratique est même plus favorable que ce que ladite directive prévoit. »
} 


\subsubsection{Economic category}

As we have explained in the previous paragraphs, the Luxembourgish regulation did not change for a long time in terms of migration policy and concerning the type of permits. Within the IMPALA database and in particular using the codification for Luxembourg, one can identify some differences in terms of conditions across some entry tracks. In this exercise, we will compare over time entry tracks for the same type of applicants. Before 2008, we use the Work Permit B, which can be considered as the most generic one. After 2008, we take the Salaried employee TCN entry track, which can also be considered as a general entry-track with few references to the degree, the professional experience and other salient features of the workers.

First, there are common aspects between the regulation in $1972^{42}$ and the one following the reform of $2008^{43}$ : (i) the sponsorship of the employer is mandatory for the delivery of a work permit, meaning that the prospective immigrant needs to have a signed work contract or a promise of employment; (ii) there are possible renewals of the permit if the conditions are fulfilled; (iii) it is possible to apply for the family reunification after a waiting period etc.

Nevertheless, an important difference between the regulations of $1972^{44}$ and 2008 is the possibility to create a list for shortage occupations (even though it was one applied in 2015 for 12 occupations). Unsurprisingly, the 2008 one is more complex and more detailed on the requested conditions mentioned in 1972.

\subsubsection{Family category}

As explained before, it is important to keep in mind that the regulation regarding the family reunification was officially created within the law of $2008^{45}$. Previously the family reunification was applied according to some administrative practice of the Ministry, with hardly no legal basis. The information available in the IMPALA database tried to capture this administrative practice.

\footnotetext{
${ }^{42}$ Loi du 28 mars 1972 concernant 1. l'entrée et le séjour des étrangers; 2. le contrôle médical des étrangers; 3. l'emploi de la main-d'oeuvre étrangère

${ }^{43}$ Loi du 29 août 2008 portant sur la libre circulation des personnes et l'immigration

${ }^{44}$ Loi du 28 mars 1972 concernant 1. l'entrée et le séjour des étrangers; 2. le contrôle médical des étrangers; 3. l'emploi de la main-d'oeuvre étrangère 45 Loi du 29 août 2008 portant sur la libre circulation des personnes et l'immigration
} 
To illustrate the evolutions of the conditions, we selected the partner of the holder of a work permit B in 1972 and the partner of a salaried employee in 2008.

The first difference we came across was the waiting period to be allowed to apply for family reunification. With a work permit $\mathrm{B}$, the minimal waiting period was 2 years. Following the new regulation in 2008, the waiting period is limited to 1 year. The second big difference is a more favorable way of evaluating the requested resources. For example, free accommodation is taken into account in 2008 which was not the case before. An additional restrictive criterion is nevertheless the mandatory social security for the sponsor (worker) and his family. As a last example, the minimum age of the partner is mentioned (18 years old) which was not explicit before (this condition of minimum age for the partner, was also introduced in the French legislation as of 2006).

The major achievement of the new regulation is not so much the modification of the criteria to be fulfilled by the sponsor and the family applicant, but the fact that for the first time a real legislative basis was available, which can be used in case of refusal and appeal before court.

\subsection{Short comparison with neighboring countries (France)}

We will compare some aspects of the Luxembourgish legislation in terms of immigration and asylum with the French legislation. In France, the important reforms that can be identified through the Impala codification took place in 1998 and in 2006 ("Immigration choisie").

The French case a comparison basis is appealing because of the similarity between the general legislation, as for example reflected by the Civil Code. In many explanatory statements in the different law projects, Luxembourg often makes references to foreign legislations and in particular to the French one.

\subsubsection{Economic group: France}

For many years the French legislation is quite advanced in terms of the variety of work permits delivered for economic reasons to foreigners. While Luxembourg relied on 3 types of work permits (A, B and C) to cover its economic immigration, France implemented 13 types of work permits (eg: Salaried employee, Temporary worker, Scientific, Artistic and cultural profession, High skill executive officer of foreign company etc.). In 2006, the number of work 
permits was increased through the implementation of new visas such as the "Skills and Talent" and "Skills and Talent from a member state of the priority solidarity zone". Many additional possibilities were also implemented such as the introduction of the long residence status for third country national deriving from the European directive 2003/109/CE.

Whereas the basic conditions for the delivery of work permit in France did not change significantly since 1990, the creation of the new type of work permit definitely reflected a willingness to be more selective in terms of economic immigrant. The main objectives were to increase the match with the domestic economic needs and to attract highly skilled workers and specific profiles ${ }^{46}$.

\subsubsection{Family group: France}

Before 1976, France did not have any specific rules for the conditions applicable to the family reunification. The decree of April 29, 1976 clarified the family reunification procedure, with conditions in terms of minimal resources for the resident already living in France, in terms of accommodation for his family and in terms of the requirement of one year of legal residence in France (the decree presented no explanations about the minimum income or the accommodation). We can compare this situation in 1976 in France with the situation in Luxembourg before the reform of 2008). The law organizing the family reunification was born.

In 1993, the Law "Pasqua" (August 24, 1993) ${ }^{47}$ placed the family reunification principle in the Ruling of November 2, $1945^{48}$. The conditions to obtain the right for family reunification became stricter. For example, the spouse of a French citizen did not obtain systematically the resident card (valid 10 years). This law was applicable for all nationalities including EU members, refugees and stateless persons.

In July $2006^{49}$ (Law July 24, 2006), the minimum duration of regular residence as a condition for family reunification was increased to 18 months, from 1 year before The

\footnotetext{
46 eg: Artistic and cultural profession and Scientific created in 1998, Skills and Talent created in 2006, Foreigner with an exceptional economic contribution to France (Investor) in 2008 etc.).

47 Loi n ${ }^{\circ}$ 93-1027 du 24 août 1993 relative à la maîtrise de l'immigration et aux conditions d'entrée, d'accueil et de séjour des étrangers en France

48Ordonnance $\mathrm{n}^{\circ} 45-2658$ du 2 novembre 1945 relative à l'entrée et au séjour des étrangers en France et portant création de l'Office national d'immigration

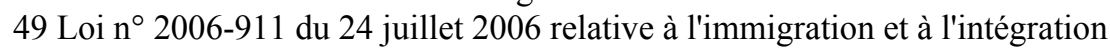


minimum income level that was required was increased to the minimum salary, net of any allocations coming from the State.

In $2007^{50}$, the law strengthened the integration condition, with an automatic evaluation of the proficiency in the French language and knowledge of the French Republic values before the delivery of the mandatory visa. A contract "Welcome contract and integration" has to be signed by the family members.

The family reunification process implemented by the administrative practice in Luxembourg before 2008 and then explicitly afterwards by the law of 2008, finally requested more or less the same main criteria. The major difference between both countries is the integration condition of the family members of migrants with an integration contract mandatory in France and only optional in Luxembourg.

\subsection{The future reform of the Luxembourgish migration policy}

Following the major reshuffle of its immigration policy, Luxembourg has already announced three new axes of reform which will be implemented in the future.

The European Union adopted in 2014 two new directives, i.e. (i) 2014/36/EU about seasonal workers and (ii) 2014/66/EU about posted workers. Both directives must be implemented in the national legislation by the end of 2016. The transposition work has already started since 2014 .

In parallel, in order to address the issue of the needs of its domestic labour market, Luxembourg has started since 2014 to reflect on two new work permits: investors and company director. As mentioned by the Minister of immigration and asylum on February 2014, “Certaines catégories peuvent être jugées prioritaires vu l'impact économique et financier qui en résultent pour le Luxembourg et leur contribution à la prospérité du pays ${ }^{\text {} 51}$. Both of them can be considered as highly skilled work permits and reflect the willingness to adopt more selective policies. In the same perspective, the adoption of the European Blue Card is under way ${ }^{52}$.

50Loi n 2007-1631 du 20 novembre 2007 relative à la maîtrise de l'immigration, à l'intégration et à l'asile 51 Extrait de la réponse parlementaire du Ministre de l'immigration et de l'asile à la question parlementaire $\mathrm{n}^{\circ}$ 70 , février 2014

52 More information about the European Blue Card can be found: www. http://ec.europa.eu/immigration/whodoes-what/what-does-the-eu-do/coming-to-the-eu_en\#higlyqual. The following conditions must fulfill in Luxembourg: (i) have an employment contract of one year at least for a job for a highly qualified worker; (ii) at 
The last axis was the adoption in 2015 of a shortage list for 10 occupations from the IT sector $^{53}$, such as software developer, database specialist or statistician. The minimum salary must be at least $20 \%$ above the minimum salary and a minimum of 5 years of experience is required. This list is the first one since the adoption of the law of 2008. This shortage lists are existing since many years in many other countries, such as France, Australia and the United states. In France for example, the shortage lists are established at the regional level, which implies a very detailed evaluation of the labour market. This signals an important future evolution. Even if this list is not currently not supposed to be extended, the mere fact that an occupation list already exists suggests that this is an important avenue of reform in the future immigration policy.

\section{Conclusion}

This article presents and discusses the evolution of immigration policy in Luxembourg. To that aim, the analysis relies on the insights provided by the IMPALA project. The IMPALA project aims at creating a database capturing the various dimensions of immigration policies in a set of important immigration countries, such as Luxembourg. Using that approach, we provide some details about the restrictions embedded in the Luxembourgish immigration laws concerning three types of prospective candidates: economic immigrants, immigrants coming under the family reunification schemes and humanitarian immigrants.

Over the years, immigration policy has become more complex and more explicit about the application process for immigrants. Economic immigration has increasingly paid more attention to the profile of the targeted immigrants. The reform of 2008 implemented many European directives and led to the creation of work permits for third country nationals that take into account the skills of immigrants. Before that, Luxembourg did not make any distinction. This was a desirable development and a necessary development in the presence of selective immigration policies that are in place in neighboring countries such as France with whom Luxembourg is in competition to attract talented workers. The recent perspective of the

least equivalent to 1.5 times the amount of the Luxembourg average gross annual salary $(47,964 \times 1.5=$ EUR 71.946 in 2015) or; at least equivalent to 1.2 times the amount of the Luxembourg average gross annual salary (47,964 x 1.2 = EUR 57.556,80 in 2015) for work in one of the following professions and for which the government has noticed a particular need to employ third-country nationals (shortage list).

53 Règlement ministériel du 13 mai 2015 fixant le salaire annuel brut moyen au titre du règlement grand-ducal modifié du 26 septembre 2008 déterminant le niveau de rémunération minimal pour un travailleur hautement qualifié en exécution de la loi du 29 août 2008 sur la libre circulation des personnes et l'immigration/ Arrêté du Gouvernement en conseil du 22 mai 2015 portant fixation du seuil salarial minimal pour l'obtention de la carte bleue européenne pour certaines professions selon les classifications CITP08 
implementation of visas based on a list of some specific professional occupations that are in need on the domestic labour market can also be seen as part of this catching-up process with the other European countries in terms of selective policies.

Another important development concerns the evolution of the conditions for family reunification. Before the reform in 2008, family reunification relied basically on administrative practices. Since 2008, the immigration law has been explicit about the application process. Conditions for getting visas based on family reunification depends on the profile of the sponsor, and in particular on the type of work permit he/she has got. Like in many countries, the recent evolution of the Luxembourgish immigration policy shows that there is a connection between economic immigration and family reunification. The conditions turn out to be less restrictive for family members of sponsors who benefit from high skill visas.

The Impala project allows to shed some light on the complexity of immigration policy. Even within one particular category such as economic immigration, policies have become increasing more diversified and selective in terms of the profile of the immigrants that are targeted. In spite of its small size, Luxembourg is no exception to this trend. Unlike the Impala data, indexes of immigration policies that provide aggregate pictures fail to capture the complexity of these policies and can provide a distorted view of the immigration policy prevailing in the host countries.

\section{References}

Adsera, A. and M. Pytlikova (2012), The role of language in shaping international migration: Evidence from OECD countries 1985-2006, The Economic Journal, 125 (286), F49-F81.

Anderson, J and E. Van Wincoop (2004), Trade Costs, Journal of Economic Litterature, 42 (3), 691-751.

ASTI/ ALOS-LDH- Luxembourg (2012), Réponse commune de ALOS-LDH et ASTILuxembourg au livre vert de la Commission européenne relatif au droit au regroupement familial COM (2011) 735 final, Ref. Ared (2012) 195298-21/02/2012

Barnich, M. (1969), L'assistance sociale aux immigrants et leur intégration sociale dans le milieu d'accueil luxembourgeois, Université internationale de sciences comparées Luxembourg, Etudes Economiques Luxembourgeoises, Conférence 1969. 
Beine, M. , S. Bertoli and J. Fernandez-Huerta-Moraga (2015), A Practitioners' Guide to Gravity Models of International Migration, joint with Simone Bertoli and, The World Economy, March, DOI: 10.1111/twec.12265.

Beine, M., P. Bourgeon, and J.-C. Bricongne (2013): Aggregate Fluctuations and International Migration," CESifo Working Paper No. 4379, Munich.

Beine, M., B.B. Burgoon; M. Crock; J. Gest; M. Hiscox; P. McGovern; H. Rapoport; E. Thielemann (2014), Measuring Immigration Policies: Preliminary Evidence from IMPALA, joint with, CESifo Economic Studies , 2015; 61 (3/4), 527-559; doi: 10.1093/cesifo/ifu038.

Beine, M., F. Docquier, and C. Ozden (2011a): Diasporas," Journal of Development Economics, 95(1), 30-41.

Belot, M., and S. Ederveen (2012): \Cultural barriers in migration between OECD countries," Journal of Population Economics, 25(3), 1077-1105.

Demig (2015), DEMIG POLICY, version 1.3, Online Edition. Oxford: International Migration Institute, University of Oxford.

Gest, J., A. Boucher, S. Challen, B. Burgoon, E. Thielemann, M. Beine, P. McGovern, M. Crock, H. Rapoport and M. Hiscox (2014), Measuring and Comparing Immigration, Asylum and Naturalization Policies Across Countries: Challenges and Solutions, Global Policy, 5, 3: 261-274.

Helbling M., L. Bjerre L., F. Roemer and M. Zobel (2013) "The immigration policies in comparison index: The importance of a sound conceptualization" Migration and Citizenship, Vol., pp. 8-15.

Kollwelter, S. (1984), Lëtzebuerg de Lëtzebuerger : Le Luxembourg face à l'immigration, Les débuts du service de l'immigration: Souvenirs de M-Marcel Barnich, premier commissaire à l'immigration, ASTI, Ed. Guy Binsfeld.

Lentz, F. (2007), L’immigration au Luxembourg, Revue Forum, Décembre 2007.

Mayda, A.-M. (2010), International Migration: A Panel Data Analysis of the Determinants of Bilateral Flows. Journal of Population Economics, 23 (4): 1249-1274.

Moyse, F. (2008), Le Luxembourg et la liberté de circulation des travailleurs européens, à l'aune de la loi du 29 août 2008 sur la libre circulation des personnes et l'immigration, Annales du droit luxembourgeois, vol. 17-18, Brussels : Bruylant 
Ortega, F. and G. Peri (2009), The Causes and Effects of International Migrations: Evidence from OECD Countries 1980-2005.’NBER Working Paper No. 14883.

Thoss, M. (1975), Déclaration de M. le Secrétaire d'Etat Thoss sur la politique d'immigration du gouvernement, Chd, C-1975-O-058-002 